\title{
CMV UL38 Gene
}

National Cancer Institute

\section{Source}

National Cancer Institute. CMV UL38 Gene. NCI Thesaurus. Code C129673.

CMV UL38, which encodes apoptosis inhibitor UL38 protein, plays a role in the modulation of host cell apoptosis. 